\title{
Integrin Regulation of CAF Differentiation and Function
}

\author{
C. Michael DiPersio * (D) and Livingston Van De Water \\ Department of Surgery, Albany Medical College, Albany, NY 12208, USA; vandewl@amc.edu \\ * Correspondence: dipersm@amc.edu
}

Received: 12 April 2019; Accepted: 21 May 2019; Published: 24 May 2019

check for updates

\begin{abstract}
Extensive remodeling of the extracellular matrix, together with paracrine communication between tumor cells and stromal cells, contribute to an "activated" tumor microenvironment that supports malignant growth and progression. These stromal cells include inflammatory cells, endothelial cells, and cancer-associated fibroblasts (CAFs). Integrins are expressed on all tumor and stromal cell types where they regulate both cell adhesion and bidirectional signal transduction across the cell membrane. In this capacity, integrins control pro-tumorigenic cell autonomous functions such as growth and survival, as well as paracrine crosstalk between tumor cells and stromal cells. The myofibroblast-like properties of cancer-associated fibroblasts (CAFs), such as robust contractility and extracellular matrix (ECM) deposition, allow them to generate both chemical and mechanical signals that support invasive tumor growth. In this review, we discuss the roles of integrins in regulating the ability of CAFs to generate and respond to extracellular cues in the tumor microenvironment. Since functions of specific integrins in CAFs are only beginning to emerge, we take advantage of a more extensive literature on how integrins regulate wound myofibroblast differentiation and function, as some of these integrin functions are likely to extrapolate to CAFs within the tumor microenvironment. In addition, we discuss the roles that integrins play in controlling paracrine signals that emanate from epithelial/tumor cells to stimulate fibroblasts/CAFs.
\end{abstract}

Keywords: integrin; tumor microenvironment; cancer-associated fibroblast (CAF); extracellular matrix; paracrine signaling

\section{Introduction}

The tumor microenvironment (TME) is an important driver of tumor growth and malignant progression. Within the TME, an "activated" stroma depends on extensive modulation of the extracellular matrix (ECM) and communication between tumor cells and cells that reside in the stroma, including tumor/cancer-associated fibroblasts (CAFs), infiltrating immune and inflammatory cells, and endothelial cells of the tumor vasculature [1-4]. Integrins are the major family of cell adhesion receptors for the ECM [5], and they are expressed on all cell types of the TME where they have critically important roles in tumor growth and malignant progression. Indeed, integrins regulate a number of cell-autonomous functions within both tumor cells and stromal cells that promote cancer, including survival, proliferation, motility/invasion, and ECM modulation, as reviewed extensively elsewhere [6-11]. In addition, roles are emerging for integrins in the regulation of intercellular communication within the TME, through their abilities to regulate paracrine signaling, either chemical or mechanical, between tumor cells and stromal cells [12,13] (Figure 1). 


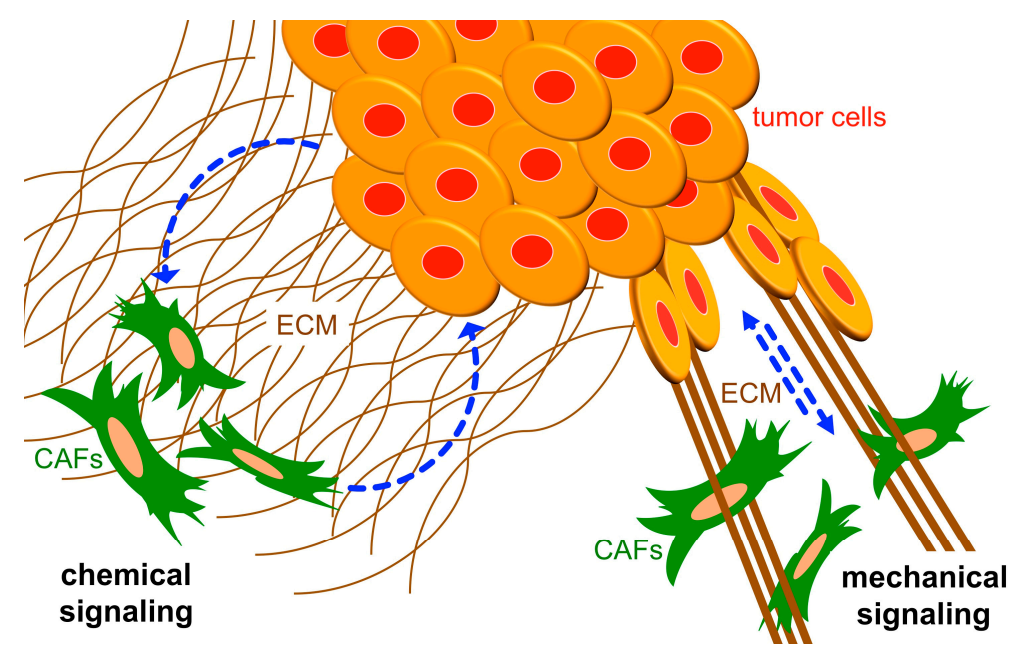

Figure 1. Integrins regulate intercellular communication in the tumor microenvironment (TME). ECM receptors (integrins) on the cell surface (not depicted in the illustration) regulate paracrine signaling between tumor cells and stromal CAFs. Paracrine signaling can be mediated by secreted factors (i.e., chemical signaling, depicted on the left) or changes in matrix stiffness (i.e., mechanical signaling, depicted on the right). ECM: extracellular matrix; CAFs: cancer-associated fibroblasts.

All integrins are heterodimeric, transmembrane glycoproteins consisting of an $\alpha$ and $\beta$ subunit, each with a cytoplasmic domain, a transmembrane domain, and a large extracellular domain. There are 24 distinct integrins that result from the dimerization of $18 \alpha$ subunits and eight $\beta$ subunits in limited combinations, each with different (albeit often overlapping) ligand-binding specificities [5]. As receptors at the cell's interface with the ECM, integrins bind simultaneously with ligands through their extracellular domains, and with cytoskeletal/signaling proteins through their cytoplasmic domains, thereby mediating both 'inside-out' and 'outside-in' signaling. In this capacity, integrins are conduits of bidirectional signal transduction that control the cell's ability to both promote and respond to biochemical and mechanical changes in the TME $[5,14]$. This regulation reflects the central roles that integrins play in the "dynamic reciprocity" between cells and the ECM that has long been appreciated [15].

As integrins have pro-tumorigenic roles in both tumor and stromal cells, and their cell surface expression renders them readily accessible to inhibitory agents, they are attractive therapeutic targets $[7,16]$. Indeed, notable clinical successes have been realized with integrin-based therapeutics that target platelet-specific integrin $\alpha \operatorname{Ilb} \beta 3$ (thrombosis), leukocyte integrins $\alpha 4 \beta 1$ and $\alpha 4 \beta 7$ (multiple sclerosis), $\alpha 4 \beta 7$ (ulcerative colitis and Crohn's disease), and $\alpha \mathrm{L} \beta 2$ (dry eye) (for recent comprehensive reviews, see $[17,18])$. However, attempts to exploit integrins as targets in the cancer clinic have so far been met with little success [19-21]. The inefficacy of integrin-targeting strategies to date can be attributed in a large part to several important limitations of current approaches. First, these approaches have focused on the use of arginine-glycine-aspartic acid (RGD)-based peptides or RGD mimetics, the first discovered peptide motif within certain ECM proteins (e.g., fibronectin, FN) that binds a small subgroup of integrins $[5,7,20]$. As a result, integrins that bind non-RGD ligands, such as laminins (LNs) or non-RGD domains of FN, remain unexplored as clinical targets despite abundant evidence from preclinical models that supports important roles in cancer $[8,22-30]$. Second, many integrin antagonists that have been tested in the cancer clinic are thought to work primarily by targeting integrins on endothelial cells of the tumor vasculature to modulate angiogenesis (e.g., $\alpha \mathrm{v} \beta 3$ or $\alpha \mathrm{v} \beta 5$ ) [7]. However, clinical strategies to target integrins on the tumor cells, CAFs, or other stromal cells, remain underdeveloped. Finally, many clinical and preclinical studies of integrin function in cancer have focused on and targeted the $\beta 1$ integrins as a group, while paying insufficient attention to the broad functional diversity among the twelve distinct $\alpha \beta$ heterodimers that comprise the $\beta 1$ 
integrin subfamily [5]. These $\beta 1$ subfamily members can bind different ligands and have distinct roles in cancer. For example, $\alpha 2 \beta 1$ is a suppressor of breast cancer metastasis [31], while $\alpha 3 \beta 1$ and $\alpha 6 \beta 1$ have pro-tumorigenic/pro-metastatic roles in breast cancer [25,32-35].

The striking discordance between decades of preclinical studies that strongly support important roles for integrins in cancer, and the disappointing results of cancer clinical trials that target integrins, reflect how the field of integrin biology has evolved to a critical juncture at which we must begin to delve more deeply into the combined roles that individual integrin $\alpha \beta$ heterodimers play within distinct cell types of the TME. Moreover, in addition to their well-established roles in regulating cell-autonomous functions, there is mounting evidence that some integrins can also regulate communication between different cell types during both normal and pathological tissue remodeling processes, as reviewed elsewhere [12,36-38]. These findings link the adhesion state of a cell-which is defined by the function of specific integrins-with its capacity to influence the phenotype of other cells. While this phenomenon is less well explored in cancer, it is likely that integrins have similarly important roles in paracrine signaling and intercellular communication in the TME to support tumor growth and progression. Indeed, as discussed below, there is much we can learn from intercellular communication between epithelial cells and fibroblasts/myofibroblasts during wound healing that may also apply to interactions between tumor cells and CAFs in the TME [39].

\section{Roles for Integrins in Controlling CAF Differentiation and Function}

It is well established that CAFs contribute to an activated stroma that promotes tumor progression and carcinoma invasion, and roles for specific integrins in this process are beginning to emerge. In the following discussion, we use the wound myofibroblast as a model for the CAF. Myofibroblasts deposit ECM exuberantly and effect its robust contraction. Indeed, the myofibroblast-like properties of CAFs are important for their ability to generate a stiff ECM within the TME that supports invasive tumor growth $[4,40,41]$. As discussed below, roles for specific integrin-ECM interactions in controlling myofibroblast differentiation and ECM rigidity are clear [42,43]. Integrins can also regulate the ability of CAFs to modulate the TME by controlling the bioavailability of ECM-bound growth factors, or the exposure/liberation of matrix protein domains/fragments with bioactivity through mechanical signaling or ECM proteolysis [44-46]. Well known examples include the local activation of the ECM-bound, latent transforming growth factor- $\beta$ (TGF- $\beta$ ) complex by certain $\alpha$ v integrins [47], or the ability of some integrins to induce or activate matrix metalloproteases (MMPs) or other extracellular proteases that release reservoirs of ECM-associated growth factors to stimulate angiogenesis or other stromal functions [44,48-50].

The remainder of this review will focus on the potential roles that integrins play in regulating CAF differentiation and function, using wound fibroblasts/myofibroblasts as a model where appropriate. Below, we discuss emerging roles for specific CAF integrins in controlling their ability to generate or respond to, mechanical and biochemical cues in the TME (Figure 2). In addition, we discuss recently discovered roles of certain integrins on epithelial cells in promoting the paracrine stimulation of fibroblasts/myofibroblasts, and the potential for such intercellular crosstalk to regulate CAF differentiation and function within the TME (Figure 3). The following sub-sections are organized around recent advances towards understanding the roles that distinct integrins, or subgroups of related integrins, play in such regulation. This organization highlights the need to understand how integrins function both individually and collectively from within distinct cellular compartments of the TME to support a pro-tumorigenic niche. We will consider roles that integrins potentially play within CAFs themselves (Figure 2), as well as within tumor cells to regulate the expression/secretion of paracrine-acting factors that stimulate CAFs (Figure 3). 


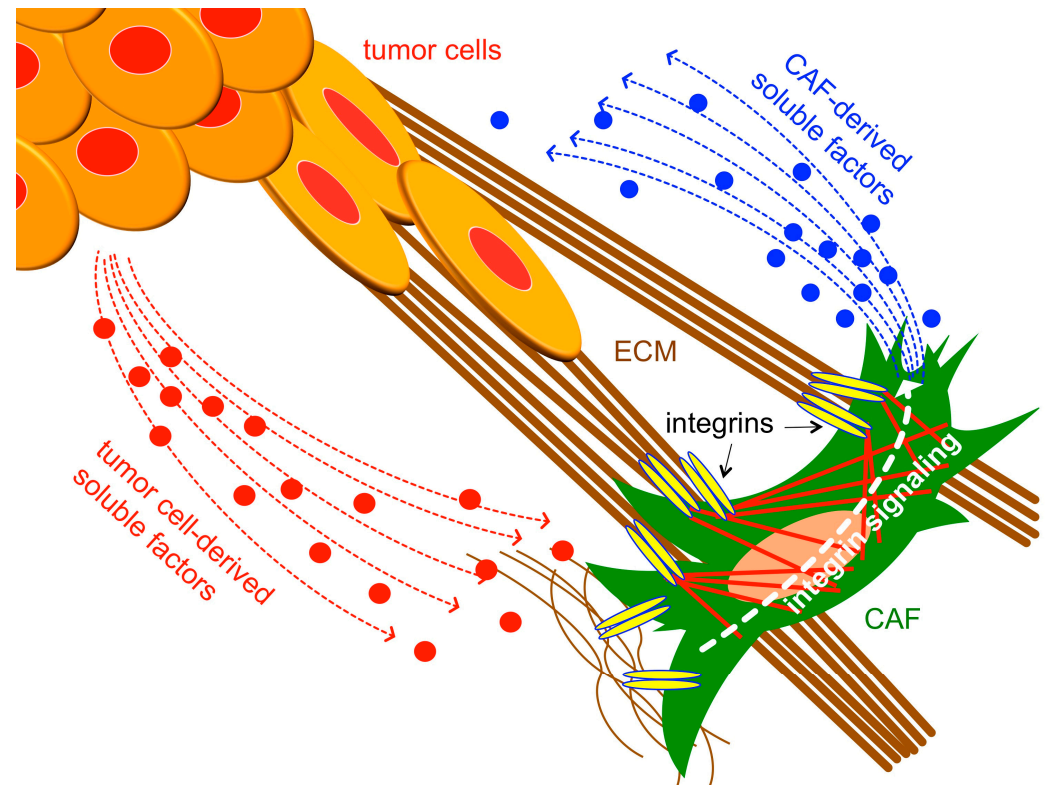

Figure 2. Integrins expressed on CAFs may control their ability to modulate the TME through both chemical signals and mechanical signals propagated through changes in ECM stiffness, as well as their ability to respond to chemical and mechanical cues from the TME.

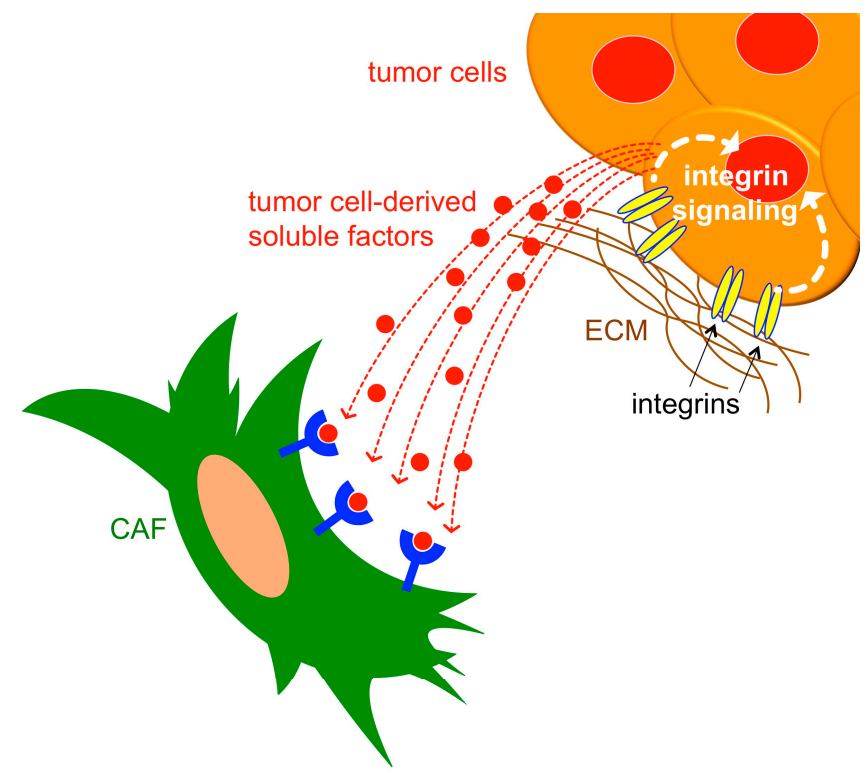

Figure 3. Integrins expressed on tumor cells regulate the expression/secretion of paracrine-acting factors that stimulate $\mathrm{CAFs}$, in some cases, through binding to receptors expressed on the CAF surface. ECM, extracellular matrix; CAFs, cancer-associated fibroblasts.

\subsection{Fibronectin-Binding Integrins}

It is well established that fibroblasts differentiate into smooth muscle cell $\alpha$-actin (SMC actin)-positive myofibroblasts in a process that requires sufficient ECM mechanical stiffness, active TGF- $\beta$, and an ECM in which FNs are deposited that include the alternatively spliced extra domain-A (EDA/EIIIA) domain [41,51]. In turn, these contractile myofibroblasts increase the mechanical stiffness of the ECM, produce more latent TGF- $\beta$, and deposit abundant interstitial collagens and FN, engaging a feed-forward loop that promotes additional myofibroblast differentiation. Importantly, these traits of myofibroblasts are likely to be shared by CAFs [39,52]. 
An exhaustive review of the literature yields few references on CAF integrins, which highlights an important knowledge gap in the field. Fortunately, wound fibroblasts and myofibroblasts provide a useful paradigm owing to their intensive study in recent years. Early work suggested an important role for FN isoforms that include the alternatively spliced EIIIA/EDA segment in TGF- $\beta$-dependent myofibroblast differentiation [53]. Importantly, EIIIA/EDA and EIIIB/EDB forms of FN are prominently expressed in tumor stroma $[4,51,54,55]$, potentially implicating the integrins that bind to them. Work also focused on identifying potential receptors that bind the EIIIA/EDA segment of fibronectin, and receptors of two types have been identified: integrins ( $\alpha 4 \beta 1, \alpha 4 \beta 7$, and $\alpha 9 \beta 1)$ [56-58] and a Toll-like receptor, TLR4 [59]. Of these, integrin $\alpha 4 \beta 1$ is expressed on a variety of primary fibroblasts and integrin $\alpha 4 \beta 7$ on primary lung fibroblasts. In contrast, $\alpha 9 \beta 1$ is prominent on epithelial cells, neutrophils, and muscle cells and appears to not be expressed by fibroblasts [60,61]. Mice engineered to express FNs at normal levels, but that constitutively lack the EIIIA/EDA segment, exhibited fewer myofibroblasts as well as reduced fibrosis in models of lung fibrosis, allergen-induced airway fibrosis, and atherogenesis [57,62]. Although no effect on the numbers of stromal myofibroblasts in a model of pancreatic cancer has been observed [63]. However, using a mouse model of myocardial infarction, Arslan and coworkers reported reduced ECM remodeling and inflammation, with improved repair, in mice expressing FN without EIIIA/EDA [64]. Collectively, these findings suggest an important role for $\alpha 4$-containing integrins, together with EIIIA/EDA FNs, in regulating fibroblast and myofibroblast function. However, their role in CAFs is an area in which more study is needed.

How do $\alpha 4$ integrins affect changes in the fibroblast/myofibroblast phenotype? Integrin $\alpha 4 \beta 1$ and EIIIA/EDA-containing FNs were reported to promote an increase in FN expression, FN matrix assembly, stress fibers, and myosin light chain phosphorylation, consistent with a role in establishing a pro-fibrogenic phenotype [65]. Integrin $\alpha 4 \beta 1$ has also been shown to promote FN matrix assembly via the CS-1 region of FN [30]. TLR4 functions in the innate immune response in immune cells and fibroblasts, and together with EIIIA/EDA FNs induces cytokine production and promotes fibrosis in a murine cutaneous model $[66,67]$. Interestingly, TLR4 may also work synergistically with $\alpha 4 \beta 1$ to promote fibrotic gene induction [68]. Together these data suggest a role for $\alpha 4$ integrins in ECM remodeling and associated changes in the cytoskeleton and potentially fibrotic gene expression. Indeed, in the bleomycin murine model, the extent of lung fibrosis was reduced coincident with diminishing numbers of myofibroblasts when mice were treated with an anti- $\alpha 4$ antibody [69]. However, the precise mechanisms through which $\alpha 4$ integrins alter the myofibroblast phenotype and the extent to which these mechanisms may extend to CAFs remain unclear.

\subsection{Collagen-Binding Integrins}

The collagen-binding integrins $\alpha 1 \beta 1, \alpha 2 \beta 1$, and $\alpha 11 \beta 1$ are expressed on fibroblasts. However, the roles of $\alpha 1 \beta 1$ and $\alpha 2 \beta 1$ in mediating critical fibroblast-mediated functions during tumorigenesis have been elusive. During wound healing, collagen deposition is a critical process that enables prompt, but imperfect, repair albeit with compromised collagen assembly. Intriguingly, while the ultrastructure of assembled collagen in excisional wounds in integrin $\alpha 2$-null vs. wild type mice was identical, subtle differences were observed in the tensile strength in the wounds of $\alpha 2 \beta 1$-deficient mice suggesting a role in collagen assembly [70]. By contrast, conspicuous roles have been observed for integrin $\alpha 11 \beta 1$, with reductions in the extent of granulation tissue formation and wound contraction observed in $\alpha 11$-null mice [71]. Indeed, integrin $\alpha 11 \beta 1$ is prominently expressed on fibroblasts, and $\alpha 11 \beta 1$ (i.e., $\alpha 11$ knockouts) leads to markedly reduced SMC actin expression and lower tensile strength of healed wounds [71]. Integrin $\alpha 11 \beta 1$ and SMC actin are both markedly upregulated in the stroma of human oral squamous cell carcinoma [72]. By breeding $\alpha 11$-null mice onto a severe combined immune deficiency (SCID) background, Navab and coworkers demonstrated reduced growth of human non-small cell lung carcinoma and adenocarcinoma in the mice lacking $\alpha 11 \beta 1$ [73]. Importantly, tumor extracts from mice lacking $\alpha 11 \beta 1$ had notably less collagen crosslinking and reduced tumor lysyl oxidase 1 expression. Lysyl oxidases are critical enzymes that crosslink collagen, thereby increasing the 
mechanical stiffness of the ECM. Because this stiff ECM is an important factor in tumor progression, these findings position integrin $\alpha 11 \beta 1$ as a key modulator of ECM stiffness in solid tumors and implicate it as a potential therapeutic target [74-76]. Collectively, these discoveries on $\alpha 11 \beta 1$, along with those on other fibroblast integrins (i.e., $\alpha 4$ integrins, see above; $\alpha 3 \beta 1$, and $\alpha \mathrm{v}$ integrins, see below), suggest that fibroblast integrins serve diverse and sometimes subtle functions that set them apart from the original discoveries of their adhesive function. Moreover, the data suggest that there exist at least partially redundant networks that promote myofibroblast differentiation, likely in both wounds and tumors, highlighting the difficulties in targeting these overlapping pathways therapeutically to blunt myofibroblast function [51].

\section{3. $\alpha v$ Integrins}

Several studies have shown that members of the $\alpha \mathrm{v}$ integrin subgroup have complex roles in the intercellular communication that occurs between tumor cells and CAFs, where they can function in both cell types to regulate biochemical and mechanical cues in the extracellular environment. In one study, CAF-secreted interleukin 32, an RGD motif-containing cytokine, was shown to bind integrin $\alpha \mathrm{v} \beta 3$ expressed on breast cancer cells to activate a p38 mitogen activated protein kinase (MAPK) signaling pathway that drives tumor cell invasion [77]. Another study used a co-culture model to identify $\alpha \mathrm{V}$ integrin on carcinoma cells as a regulator of directional migration in response to CAF-mediated FN fibrillogenesis and alignment [78]. Interestingly, $\mathrm{FN}$ organization by CAFs required myosin-II-driven contractility and increased traction forces that were transduced to the ECM through integrin $\alpha 5 \beta 1$ [78], providing a clear example of how coordinated functions of different integrins expressed on CAFs and tumor cells could regulate their intercellular communication. Certain $\alpha \mathrm{v}$ integrins can also stimulate cancer cell invasion from within CAFs. For example, $\alpha v \beta 3$ was shown to be essential for CAF-mediated FN assembly that stimulated the invasion of colon carcinoma cells [79]. Finally, integrins can also regulate the ability of CAFs to stimulate inflammation in the TME that supports tumor growth and progression. Indeed, a recent study in breast cancer cells identified secreted osteopontin as a mediator of paracrine signaling to stromal fibroblasts that activates a pro-inflammatory CAF phenotype through binding to its receptors, integrin $\alpha \mathrm{v} \beta 3$, and CD44 [80].

As indicated above, ECM remodeling is proving to be a critical aspect of myofibroblast and CAF differentiation. This is particularly germane for TGF- $\beta$, which is stored in the wound ECM as a "large" latent complex from which active TGF- $\beta$ is released in an integrin $\alpha \mathrm{v}$-dependent process. The latency-associated protein (LAP)— to which TGF- $\beta$ is bound non-covalently-is covalently attached to the latent TGF- $\beta$ binding protein, which is bound to fibronectin and fibulin within the ECM $[45,81]$. The liberation of active TGF- $\beta$ from this complex can occur by several mechanisms (e.g., proteolysis; thrombospondin) depending on the cell type. Epithelial cells and many cancer cells express integrin $\alpha v \beta 6$, which activates latent TGF- $\beta$ by binding to the RGD sequence within LAP and releases active TGF- $\beta$ from the latency complex [82]. Recent data suggest that this $\alpha v \beta 6$-dependent, TGF- $\beta$ activation can function as a paracrine mechanism that induces the myofibroblast phenotype in CAFs, which in turn can produce a pro-metastatic chemokine (e.g., SDF-1/CXCL12) [83,84]. Importantly, fibroblasts and myofibroblast-bearing integrins (i.e., $\alpha \mathrm{V} \beta 3, \alpha \mathrm{V} \beta 5$ ) also release TGF- $\beta$ from an ECM that is mechanically stiff in a process that requires robust cell contraction $[81,85]$. Importantly, recent data demonstrate that EDA-containing forms of FN promote the recruitment of the large latent TGF- $\beta$ complex to the ECM deposited by fibroblasts [86], potentially implicating $\alpha 4 \beta 1$ in this regulation (see above). Despite the central function of active TGF- $\beta$ in myofibroblast and CAF differentiation, there are many processes (e.g., inflammation) mediated by this factor. Hence, targeting TGF- $\beta$ safely as a therapy is not a viable option. Instead, it has recently been proposed that the ECM itself may serve as a useful therapeutic target given its role in establishing feed-forward loops that promote myofibroblast differentiation [43], an idea that further implicates its integrin receptors as potential targets. 


\subsection{Laminin-Binding Integrins}

The laminin-binding integrins are emerging as important regulators of CAF function within the TME. This regulation can occur within CAFs themselves, or within tumor cells to control paracrine crosstalk with CAFs. Among the LN-binding integrins, $\alpha 3 \beta 1$ is the best studied in this regard as discussed below.

\subsubsection{Integrin $\alpha 3 \beta 1$ Binding to Laminin-332 Promotes CAF Differentiation and Function}

Published studies have implicated LNs, sometimes in coordination with other ECM proteins, in regulating the ability of CAFs to support a pro-invasive TME. For example, $\alpha 3 \beta 1$ (an LN receptor) and $\alpha 5 \beta 1$ (an FN receptor) were each found to be required on CAFs for protease- and force-mediated ECM remodeling to generate matrix tracks that guide collective invasion of adjacent carcinoma cells, with indications that these two integrins work through distinct signaling pathways (Rho-dependent in CAFs; Cdc42-dependent in carcinoma cells) [87]. In another recent study, Cavaco and coworkers demonstrated a critical role for $\alpha 3 \beta 1$, and its interaction with laminin-332 (LN-332), in CAF differentiation and maintenance [88]. Using CRISPR-Cas9 to generate CAFs with a knockout of the ITGA3 gene (which encodes the $\alpha 3$ integrin subunit), the authors showed that $\alpha 3 \beta 1$ is essential for the ability of CAFs to promote invasion of pancreatic duct adenocarcinoma cells (AsPC-1) in a spheroid co-culture model. Moreover, CAFs contributed to the ectopic deposition of LN-332 in this model, and presumably to the activation of $\alpha 3 \beta 1$. Interestingly, the authors used a function-blocking antibody to rule out a requirement for $\alpha 6$ integrins (which also bind LN-332), identifying $\alpha 3 \beta 1$ as the primary receptor for LN-332-mediated effects on CAFs [88].

\subsubsection{Integrin $\alpha 3 \beta 1$ in Epithelial Cells Regulates the Paracrine Stimulation of Stromal Cells}

Many studies over the last two decades have used genetic approaches or integrin blocking antibodies to establish a critical role for integrin $\alpha 3 \beta 1$ in regulating the secretion of numerous proteins by epidermal keratinocytes that modulate the skin microenvironment, including growth factors, extracellular proteases, and ECM/matricellular proteins (reviewed in $[13,38]$ ). Interestingly, $\alpha 3 \beta 1$-dependent induction of the genes that encode many of these proteins occurred in immortalized/ transformed keratinocytes but not primary keratinocytes, suggesting that gene regulatory functions of $\alpha 3 \beta 1$ may be acquired by immortalized or activated keratinocytes [89-91]. Our mass spectrometry (MS)-based proteomic analysis of secreted proteins from wild type versus $\alpha 3$-null immortalized keratinocytes confirmed that $\alpha 3 \beta 1$ is an important regulator of the keratinocyte secretome $([92,93]$, and unpublished data). Consistently, a recent study from the Has group showed that the secretome is altered in keratinocytes isolated from patients with interstitial lung disease, nephrotic syndrome, and epidermolysis bullosa (ILNEB), which lack $\alpha 3 \beta 1$ due to inherited mutations in the ITGA3 gene [94]. Indeed, MS analysis revealed that the profile of secreted proteins was altered in ILNEB keratinocytes, including a shift towards the deposition of a FN-rich matrix and upregulation of FN-binding integrins ( $\alpha 5 \beta 1$ and $\alpha \mathrm{v}$ integrins). Collectively, the above studies show that $\alpha 3 \beta 1$ regulates the epidermal secretome during normal and pathological tissue remodeling.

It has long been known that growth factors and cytokines produced by the epidermal or tumor cell compartment can diffuse into the adjacent stroma to stimulate endothelial cells, fibroblasts, and immune cells [95-98]. Some keratinocyte integrins can regulate growth factor expression, leading to paracrine stimulation of stromal cells. For example, deletion of $\alpha 3 \beta 1$ specifically from the epidermis leads to impaired wound angiogenesis in vivo, and immortalized $\alpha 3$-null keratinocytes show reduced expression of at least two pro-angiogenic factors, mitogen-regulated protein 3 (MRP-3) and MMP-9 $[90,99,100]$. Of note, both MMP-9 and MRP family members have been linked to tumor angiogenesis $[48,101,102]$, suggesting that $\alpha 3 \beta 1$ on tumor cells might similarly regulate paracrine stimulation of endothelial cells in the tumor vasculature. Strong literature supports similar crosstalk from keratinocytes to stromal fibroblasts in both tumors and wounds, as reviewed elsewhere [37,39,103], 
and co-culture studies have demonstrated that keratinocyte-derived growth factors, ECM proteins, and MMPs can induce gene expression programs in fibroblasts [104].

Although roles for specific integrins in controlling paracrine signaling from tumor cells to CAFs are only beginning to be explored, recent findings of $\alpha 3 \beta 1$-dependent crosstalk from keratinocytes to dermal fibroblasts in the wound microenvironment may offer clues. Indeed, we recently identified a novel role for epidermal $\alpha 3 \beta 1$ in the crosstalk from keratinocytes to dermal fibroblasts that regulates the differentiated state [93]. Specifically, we showed that $\alpha 3 \beta 1$ is required for paracrine signaling from keratinocytes that stimulates Cox- 2 expression/PGE 2 signaling and suppresses TGF- $\beta$-induced $\alpha$-SMA expression in fibroblasts, and that this effect is mediated through $\alpha 3 \beta 1$-dependent production by keratinocytes of interleukin-1 $\alpha$ (IL-1 $\alpha$ ) [93]. Importantly, IL- $1 \alpha$ has been shown to regulate myofibroblast differentiation in keratinocyte-fibroblast co-cultures, implicating this cytokine in the temporal control of myofibroblast differentiation during wound healing [105]. Interestingly, tumor cell-associated IL- $1 \alpha$ can also mediate the paracrine stimulation of CAFs to induce a pro-inflammatory phenotype in a co-culture model of pancreatic ductal adenocarcinoma $[106,107]$. Ongoing studies in our group are exploring whether $\alpha 3 \beta 1$ on tumor cells influences CAF differentiation or function within the TME, through the secretion of IL-1 $\alpha$ or other paracrine factors.

\section{Conclusions}

Given the distinct roles that individual integrins have been shown to play in regulating the differentiation and function of myofibroblasts or CAFs, and the importance of intercellular communication to maintain a tumor-supportive stroma, it is becoming increasingly clear that a complete understanding of integrin control over the TME must take into consideration the combined roles of individual integrins within distinct cell types of the tumor and its stroma. Indeed, this mind-set will almost certainly be essential as the field moves towards developing effective combinatorial strategies to target integrins in the cancer clinic. While there is still much to learn about the complex roles that integrins play in CAFs, it is instructive to consider the emerging paradigms for integrin regulation of myofibroblasts in wound healing or fibrotic conditions, as it seems likely that similar regulations will also apply to CAFs in the TME.

Author Contributions: C.M.D. and L.V.D.W. each contributed to the conceptualization, writing (original draft preparation, review, and editing), and acquisition of funding.

Funding: Research in the DiPersio and Van De Water laboratories is supported by the National Institutes of Health grants from NCI (R01CA129637 to C. M. DiPersio) and NIAMS (R01AR063778 to L. Van De Water and C. M. DiPersio).

Acknowledgments: The authors are grateful to colleagues at Albany Medical College and members of the Van De Water and DiPersio laboratories for their valuable discussions and insights. We offer our apologies to the many researchers whose valuable contributions to the field could not be included in this review due to space restrictions.

Conflicts of Interest: The authors declare no conflict of interest.

\section{References}

1. Hanahan, D.; Weinberg, R.A. Hallmarks of cancer: The next generation. Cell 2011, 144, 646-674. [CrossRef] [PubMed]

2. Joyce, J.A.; Pollard, J.W. Microenvironmental regulation of metastasis. Nat. Rev. Cancer 2009, 9, 239-252. [CrossRef] [PubMed]

3. Marcucci, F.; Bellone, M.; Caserta, C.A.; Corti, A. Pushing tumor cells towards a malignant phenotype: Stimuli from the microenvironment, intercellular communications and alternative roads. Int. J. Cancer 2014, 135, 1265-1276. [CrossRef]

4. Alexander, J.; Cukierman, E. Stromal dynamic reciprocity in cancer: Intricacies of fibroblastic-ECM interactions. Curr. Opin. Cell Biol. 2016, 42, 80-93. [CrossRef] [PubMed]

5. Hynes, R.O. Integrins: Bidirectional, allosteric signaling machines. Cell 2002, 110, 673-687. [CrossRef]

6. Brakebusch, C.; Bouvard, D.; Stanchi, F.; Sakai, T.; Fassler, R. Integrins in invasive growth. J. Clin. Investig. 2002, 109, 999-1006. [CrossRef] 
7. Desgrosellier, J.S.; Cheresh, D.A. Integrins in cancer: Biological implications and therapeutic opportunities. Nat. Rev. Cancer 2010, 10, 9-22. [CrossRef] [PubMed]

8. Stipp, C.S. Laminin-binding integrins and their tetraspanin partners as potential antimetastatic targets. Expert Rev. Mol. Med. 2010, 12, e3. [CrossRef]

9. Missan, D.S.; DiPersio, C.M. Integrin control of tumor invasion. Crit. Rev. Eukaryot. Gene Expr. 2012, 22, 309-324. [CrossRef]

10. Lim, Y.Z.; South, A.P. Tumour-stroma crosstalk in the development of squamous cell carcinoma. Int. J. Biochem. Cell Biol. 2014, 53, 450-458. [CrossRef] [PubMed]

11. Keely, P.; Parise, L.; Juliano, R. Integrins and GTPases in tumour cell growth, motility and invasion. Trends Cell Biol. 2000, 8, 101-106. [CrossRef]

12. Brucher, B.L.; Jamall, I.S. Cell-cell communication in the tumor microenvironment, carcinogenesis, and anticancer treatment. Cell. Physiol. Biochem. Int. J. Exp. Cell. Physiol. Biochem. Pharmacol. 2014, 34, $213-243$. [CrossRef] [PubMed]

13. Longmate, W.; DiPersio, C.M. Beyond adhesion: Emerging roles for integrins in control of the tumor microenvironment. F1000Research 2017, 6, 1612. [CrossRef] [PubMed]

14. Schwartz, M.A.; Ginsberg, M.H. Networks and crosstalk: Integrin signalling spreads. Nat. Cell Biol. 2002, 4, E65-E68. [CrossRef] [PubMed]

15. Bissell, M.J.; Hall, H.G.; Parry, G. How does the extracellular matrix direct gene expression? J. Theor. Biol. 1982, 99, 31-68. [CrossRef]

16. Stupp, R.; Ruegg, C. Integrin inhibitors reaching the clinic. J. Clin. Oncol. 2007, 25, 1637-1638. [CrossRef]

17. Ley, K.; Rivera-Nieves, J.; Sandborn, W.J.; Shattil, S. Integrin-based therapeutics: Biological basis, clinical use and new drugs. Nat. Rev. Drug Discov. 2016, 15, 173-183. [CrossRef]

18. Vicente-Manzanares, M.; Sanchez-Madrid, F. Targeting the integrin interactome in human disease. Curr. Opin. Cell Biol. 2018, 55, 17-23. [CrossRef] [PubMed]

19. Weller, M.; Nabors, L.B.; Gorlia, T.; Leske, H.; Rushing, E.; Bady, P.; Hicking, C.; Perry, J.; Hong, Y.K.; Roth, P.; et al. Cilengitide in newly diagnosed glioblastoma: Biomarker expression and outcome. Oncotarget 2016, 7, 15018-15032. [CrossRef]

20. Paolillo, M.; Serra, M.; Schinelli, S. Integrins in glioblastoma: Still an attractive target? Pharmacol. Res. 2016, 113, 55-61. [CrossRef]

21. Murphy, P.A.; Begum, S.; Hynes, R.O. Tumor angiogenesis in the absence of fibronectin or its cognate integrin receptors. PLoS ONE 2015, 10, e0120872. [CrossRef] [PubMed]

22. Subbaram, S.; DiPersio, C.M. Integrin alpha3beta1 as a breast cancer target. Expert Opin. Ther. Targets 2011, 15, 1197-1210. [CrossRef]

23. Stewart, R.L.; O'Connor, K.L. Clinical significance of the integrin $\alpha 6 \beta 4$ in human malignancies. Lab. Investig. 2015, 95, 976-986. [CrossRef]

24. Weaver, V.M.; Lelievre, S.; Lakins, J.N.; Chrenek, M.A.; Jones, J.C.; Giancotti, F.; Werb, Z.; Bissell, M.J. $\beta 4$ integrin-dependent formation of polarized three-dimensional architecture confers resistance to apoptosis in normal and malignant mammary epithelium. Cancer Cell 2002, 2, 205-216. [CrossRef]

25. Mitchell, K.; Svenson, K.B.; Longmate, W.M.; Gkirtzimanaki, K.; Sadej, R.; Wang, X.; Zhao, J.; Eliopoulos, A.G.; Berditchevski, F.; DiPersio, C.M. Suppression of integrin $\alpha 3 \beta 1$ in breast cancer cells reduces cyclooxygenase-2 gene expression and inhibits tumorigenesis, invasion, and cross-talk to endothelial cells. Cancer Res. 2010, 70, 6359-6367. [CrossRef]

26. Sachs, N.; Secades, P.; van Hulst, L.; Kreft, M.; Song, J.Y.; Sonnenberg, A. Loss of integrin $\alpha 3$ prevents skin tumor formation by promoting epidermal turnover and depletion of slow-cycling cells. Proc. Natl. Acad. Sci. USA 2012, 109, 21468-21473. [CrossRef]

27. Chung, J.; Bachelder, R.E.; Lipscomb, E.A.; Shaw, L.M.; Mercurio, A.M. Integrin ( $\alpha 6 \beta$ 4) regulation of eIF-4E activity and VEGF translation: A survival mechanism for carcinoma cells. J. Cell Biol. 2002, 158, 165-174. [CrossRef] [PubMed]

28. Goel, H.L.; Gritsko, T.; Pursell, B.; Chang, C.; Shultz, L.D.; Greiner, D.L.; Norum, J.H.; Toftgard, R.; Shaw, L.M.; Mercurio, A.M. Regulated splicing of the $\alpha 6$ integrin cytoplasmic domain determines the fate of breast cancer stem cells. Cell Rep. 2014, 7, 747-761. [CrossRef]

29. Davis, T.L.; Cress, A.E.; Dalkin, B.L.; Nagle, R.B. Unique expression pattern of the $\alpha 6 \beta 4$ integrin and laminin-5 in human prostate carcinoma. Prostate 2001, 46, 240-248. [CrossRef] 
30. Sechler, J.L.; Cumiskey, A.M.; Gazzola, D.M.; Schwarzbauer, J.E. A novel RGD-independent fibronectin assembly pathway initiated by $\alpha 4 \beta 1$ integrin binding to the alternatively spliced V region. J. Cell Sci. 2000, 113, 1491-1498. [PubMed]

31. Ramirez, N.E.; Zhang, Z.; Madamanchi, A.; Boyd, K.L.; O’Rear, L.D.; Nashabi, A.; Li, Z.; Dupont, W.D.; Zijlstra, A.; Zutter, M.M. The $\alpha(2) \beta(1)$ integrin is a metastasis suppressor in mouse models and human cancer. J. Clin. Invest. 2011, 121, 226-237. [CrossRef]

32. Yang, X.H.; Richardson, A.L.; Torres-Arzayus, M.I.; Zhou, P.; Sharma, C.; Kazarov, A.R.; Andzelm, M.M.; Strominger, J.L.; Brown, M.; Hemler, M.E. CD151 accelerates breast cancer by regulating $\alpha 6$ integrin function, signaling, and molecular organization. Cancer Res. 2008, 68, 3204-3213. [CrossRef]

33. Wang, H.; Fu, W.; Im, J.H.; Zhou, Z.; Santoro, S.A.; Iyer, V.; DiPersio, C.M.; Yu, Q.C.; Quaranta, V.; Al-Mehdi, A.; et al. Tumor cell $\alpha 3 \beta 1$ integrin and vascular laminin-5 mediate pulmonary arrest and metastasis. J. Cell Biol. 2004, 164, 935-941. [CrossRef] [PubMed]

34. Mercurio, A.M.; Bachelder, R.E.; Chung, J.; O'Connor, K.L.; Rabinovitz, I.; Shaw, L.M.; Tani, T. Integrin laminin receptors and breast carcinoma progression. J. Mammary Gland Biol. Neoplasia 2001, 6, $299-309$. [CrossRef]

35. Zhou, B.; Gibson-Corley, K.N.; Herndon, M.E.; Sun, Y.; Gustafson-Wagner, E.; Teoh-Fitzgerald, M.; Domann, F.E.; Henry, M.D.; Stipp, C.S. Integrin $\alpha 3 \beta 1$ can function to promote spontaneous metastasis and lung colonization of invasive breast carcinoma. Mol. Cancer Res. 2014, 12, 143-154. [CrossRef]

36. Janes, S.M.; Watt, F.M. New roles for integrins in squamous-cell carcinoma. Nat. Rev. Cancer 2006, 6, 175-183. [CrossRef]

37. DiPersio, C.M.; Zheng, R.; Kenney, J.; Van De Water, L. Integrin-mediated regulation of epidermal wound functions. Cell Tissue Res. 2016, 365, 467-482. [CrossRef]

38. Longmate, W.M.; DiPersio, C.M. Integrin Regulation of Epidermal Functions in Wounds. Adv. Wound Care 2014, 3, 229-246. [CrossRef] [PubMed]

39. Schafer, M.; Werner, S. Cancer as an overhealing wound: An old hypothesis revisited. Nat. Rev. Mol. Cell Biol. 2008, 9, 628-638. [CrossRef] [PubMed]

40. Kharaishvili, G.; Simkova, D.; Bouchalova, K.; Gachechiladze, M.; Narsia, N.; Bouchal, J. The role of cancer-associated fibroblasts, solid stress and other microenvironmental factors in tumor progression and therapy resistance. Cancer Cell Int. 2014, 14, 41. [CrossRef]

41. Hinz, B. The myofibroblast: Paradigm for a mechanically active cell. J. Biomech. 2010, 43, 146-155. [CrossRef]

42. Hinz, B.; McCulloch, C.A.; Coelho, N.M. Mechanical regulation of myofibroblast phenoconversion and collagen contraction. Exp. Cell Res. 2019, 379, 119-128. [CrossRef] [PubMed]

43. Walraven, M.; Hinz, B. Therapeutic approaches to control tissue repair and fibrosis: Extracellular matrix as a game changer. Matrix Biol. 2018, 71, 205-224. [CrossRef] [PubMed]

44. Schenk, S.; Quaranta, V. Tales from the crypt[ic] sites of the extracellular matrix. Trends Cell Biol. 2003, 13, 366-375. [CrossRef]

45. Hynes, R.O. The extracellular matrix: Not just pretty fibrils. Science 2009, 326, 1216-1219. [CrossRef]

46. Vogel, V.; Sheetz, M.P. Cell fate regulation by coupling mechanical cycles to biochemical signaling pathways. Curr. Opin. Cell Biol. 2009, 21, 38-46. [CrossRef]

47. Sheppard, D. Integrin-mediated activation of latent transforming growth factor $\beta$. Cancer Metastasis Rev. 2005, 24, 395-402. [CrossRef]

48. Bergers, G.; Brekken, R.; McMahon, G.; Vu, T.H.; Itoh, T.; Tamaki, K.; Tanzawa, K.; Thorpe, P.; Itohara, S.; Werb, Z.; et al. Matrix metalloproteinase-9 triggers the angiogenic switch during carcinogenesis. Nat. Cell Biol. 2000, 2, 737-744. [CrossRef]

49. McCawley, L.J.; Matrisian, L.M. Matrix metalloproteinases: they're not just for matrix anymore! Curr. Opin. Cell Biol. 2001, 13, 534-540. [CrossRef]

50. McCawley, L.J.; Matrisian, L.M. Tumor progression: Defining the soil round the tumor seed. Curr. Biol. 2001, 11, R25-R27. [CrossRef]

51. Van De Water, L.; Varney, S.; Tomasek, J.J. Mechanoregulation of the Myofibroblast in Wound Contraction, Scarring, and Fibrosis: Opportunities for New Therapeutic Intervention. Adv. Wound Care 2013, 2, $122-141$. [CrossRef]

52. Dvorak, H.F. Tumors: Wounds that do not heal. Similarities between tumor stroma generation and wound healing. N. Engl. J. Med. 1986, 315, 1650-1659. [PubMed] 
53. Serini, G.; Bochaton-Piallat, M.L.; Ropraz, P.; Geinoz, A.; Borsi, L.; Zardi, L.; Gabbiani, G. The fibronectin domain ED-A is crucial for myofibroblastic phenotype induction by transforming growth factor- $\beta 1$. J. Cell Biol. 1998, 142, 873-881. [CrossRef]

54. Brown, L.F.; Guidi, A.J.; Schnitt, S.J.; Van De Water, L.; Iruela-Arispe, M.L.; Yeo, T.K.; Tognazzi, K.; Dvorak, H.F. Vascular stroma formation in carcinoma in situ, invasive carcinoma, and metastatic carcinoma of the breast. Clin. Cancer Res. 1999, 5, 1041-1056.

55. Naba, A.; Clauser, K.R.; Hoersch, S.; Liu, H.; Carr, S.A.; Hynes, R.O. The matrisome: In silico definition and in vivo characterization by proteomics of normal and tumor extracellular matrices. Mol. Cell. Proteomics MCP 2012, 11, M111.014647. [CrossRef]

56. Liao, Y.F.; Gotwals, P.J.; Koteliansky, V.E.; Sheppard, D.; Van De Water, L. The EIIIA segment of fibronectin is a ligand for integrins $\alpha 9 \beta 1$ and $\alpha 4 \beta 1$ providing a novel mechanism for regulating cell adhesion by alternative splicing. J. Biol. Chem. 2002, 277, 14467-14474. [CrossRef]

57. Kohan, M.; Muro, A.F.; White, E.S.; Berkman, N. EDA-containing cellular fibronectin induces fibroblast differentiation through binding to $\alpha 4 \beta 7$ integrin receptor and MAPK/Erk 1/2-dependent signaling. FASEB J. 2010, 24, 4503-4512. [CrossRef]

58. Shinde, A.V.; Bystroff, C.; Wang, C.; Vogelezang, M.G.; Vincent, P.A.; Hynes, R.O.; Van De Water, L. Identification of the peptide sequences within the EIIIA (EDA) segment of fibronectin that mediate integrin $\alpha 9 \beta 1$-dependent cellular activities. J. Biol. Chem. 2008, 283, 2858-2870. [CrossRef]

59. Okamura, Y.; Watari, M.; Jerud, E.S.; Young, D.W.; Ishizaka, S.T.; Rose, J.; Chow, J.C.; Strauss, J.F., 3rd. The extra domain A of fibronectin activates Toll-like receptor 4. J. Biol. Chem. 2001, 276, 10229-10233. [CrossRef]

60. Gailit, J.; Pierschbacher, M.; Clark, R.A. Expression of functional $\alpha 4 \beta 1$ integrin by human dermal fibroblasts. J. Invest. Dermatol. 1993, 100, 323-328. [CrossRef]

61. Palmer, E.L.; Ruegg, C.; Ferrando, R.; Pytela, R.; Sheppard, D. Sequence and tissue distribution of the integrin $\alpha 9$ subunit, a novel partner of $\beta 1$ that is widely distributed in epithelia and muscle. J. Cell Biol. 1993, 123, 1289-1297. [CrossRef]

62. Tan, M.H.; Sun, Z.; Opitz, S.L.; Schmidt, T.E.; Peters, J.H.; George, E.L. Deletion of the alternatively spliced fibronectin EIIIA domain in mice reduces atherosclerosis. Blood 2004, 104, 11-18. [CrossRef]

63. Astrof, S.; Crowley, D.; George, E.L.; Fukuda, T.; Sekiguchi, K.; Hanahan, D.; Hynes, R.O. Direct test of potential roles of EIIIA and EIIIB alternatively spliced segments of fibronectin in physiological and tumor angiogenesis. Mol. Cell Biol. 2004, 24, 8662-8670. [CrossRef]

64. Arslan, F.; Smeets, M.B.; Riem Vis, P.W.; Karper, J.C.; Quax, P.H.; Bongartz, L.G.; Peters, J.H.; Hoefer, I.E.; Doevendans, P.A.; Pasterkamp, G.; et al. Lack of fibronectin-EDA promotes survival and prevents adverse remodeling and heart function deterioration after myocardial infarction. Circ. Res. 2011, 108, 582-592. [CrossRef]

65. Shinde, A.V.; Kelsh, R.; Peters, J.H.; Sekiguchi, K.; Van De Water, L.; McKeown-Longo, P.J. The $\alpha 4 \beta 1$ integrin and the EDA domain of fibronectin regulate a profibrotic phenotype in dermal fibroblasts. Matrix Biol. 2015, 41, 26-35. [CrossRef]

66. Kelsh, R.; You, R.; Horzempa, C.; Zheng, M.; McKeown-Longo, P.J. Regulation of the innate immune response by fibronectin: Synergism between the III-1 and EDA domains. PLoS ONE 2014, 9, e102974. [CrossRef]

67. Bhattacharyya, S.; Tamaki, Z.; Wang, W.; Hinchcliff, M.; Hoover, P.; Getsios, S.; White, ES.; Varga, J. FibronectinEDA promotes chronic cutaneous fibrosis through Toll-like receptor signaling. Sci. Transl. Med. 2014, 6, 232ra250. [CrossRef]

68. Kelsh-Lasher, R.M.; Ambesi, A.; Bertram, C.; McKeown-Longo, P.J. Integrin $\alpha 4 \beta 1$ and TLR4 Cooperate to Induce Fibrotic Gene Expression in Response to Fibronectin's EDA Domain. J. Invest. Dermatol. 2017, 137, 2505-2512. [CrossRef]

69. Wang, Q.; Wang, Y.; Hyde, D.M.; Gotwals, P.J.; Lobb, R.R.; Ryan, S.T.; Giri, S.N. Effect of antibody against integrin $\alpha 4$ on bleomycin-induced pulmonary fibrosis in mice. Biochem. Pharmacol. 2000, 60, 1949-1958. [CrossRef]

70. Zweers, M.C.; Davidson, J.M.; Pozzi, A.; Hallinger, R.; Janz, K.; Quondamatteo, F.; Leutgeb, B.; Krieg, T.; Eckes, B. Integrin $\alpha 2 \beta 1$ is required for regulation of murine wound angiogenesis but is dispensable for reepithelialization. J. Invest. Dermatol. 2007, 127, 467-478. [CrossRef]

71. Schulz, J.N.; Zeltz, C.; Sorensen, I.W.; Barczyk, M.; Carracedo, S.; Hallinger, R.; Niehoff, A.; Eckes, B.; Gullberg, D. Reduced granulation tissue and wound strength in the absence of $\alpha 11 \beta 1$ integrin. J. Invest. Dermatol. 2015, 135, 1435-1444. [CrossRef] 
72. Parajuli, H.; Teh, M.T.; Abrahamsen, S.; Christoffersen, I.; Neppelberg, E.; Lybak, S.; Osman, T.; Johannessen, A.C.; Gullberg, D.; Skarstein, K.; et al. Integrin $\alpha 11$ is overexpressed by tumour stroma of head and neck squamous cell carcinoma and correlates positively with $\alpha$ smooth muscle actin expression. J. Oral. Pathol. Med. 2017, 46, 267-275. [CrossRef]

73. Navab, R.; Strumpf, D.; To, C.; Pasko, E.; Kim, K.S.; Park, C.J.; Hai, J.; Liu, J.; Jonkman, J.; Barczyk, M.; et al. Integrin $\alpha 11 \beta 1$ regulates cancer stromal stiffness and promotes tumorigenicity and metastasis in non-small cell lung cancer. Oncogene 2016, 35, 1899-1908. [CrossRef]

74. Levental, K.R.; Yu, H.; Kass, L.; Lakins, J.N.; Egeblad, M.; Erler, J.T.; Fong, S.F.; Csiszar, K.; Giaccia, A.; Weninger, W.; et al. Matrix crosslinking forces tumor progression by enhancing integrin signaling. Cell 2009, 139, 891-906. [CrossRef]

75. Zeltz, C.; Gullberg, D. The integrin-collagen connection-A glue for tissue repair? J. Cell Sci. 2016, 129, 653-664. [CrossRef]

76. Multhaupt, H.A.; Leitinger, B.; Gullberg, D.; Couchman, J.R. Extracellular matrix component signaling in cancer. Adv. Drug Deliv. Rev. 2016, 97, 28-40. [CrossRef]

77. Wen, S.; Hou, Y.; Fu, L.; Xi, L.; Yang, D.; Zhao, M.; Qin, Y.; Sun, K.; Teng, Y.; Liu, M. Cancer-associated fibroblast (CAF)-derived IL32 promotes breast cancer cell invasion and metastasis via integrin $\beta 3-p 38$ MAPK signalling. Cancer Lett. 2019, 442, 320-332. [CrossRef]

78. Erdogan, B.; Ao, M.; White, L.M.; Means, A.L.; Brewer, B.M.; Yang, L.; Washington, M.K.; Shi, C.; Franco, O.E.; Weaver, A.M.; et al. Cancer-associated fibroblasts promote directional cancer cell migration by aligning fibronectin. J. Cell Biol. 2017, 216, 3799-3816. [CrossRef]

79. Attieh, Y.; Clark, A.G.; Grass, C.; Richon, S.; Pocard, M.; Mariani, P.; Elkhatib, N.; Betz, T.; Gurchenkov, B.; Vignjevic, D.M. Cancer-associated fibroblasts lead tumor invasion through integrin- $\beta 3$-dependent fibronectin assembly. J. Cell Biol. 2017, 216, 3509-3520. [CrossRef]

80. Sharon, Y.; Raz, Y.; Cohen, N.; Ben-Shmuel, A.; Schwartz, H.; Geiger, T.; Erez, N. Tumor-derived osteopontin reprograms normal mammary fibroblasts to promote inflammation and tumor growth in breast cancer. Cancer Res. 2015, 75, 963-973. [CrossRef]

81. Hinz, B. The extracellular matrix and transforming growth factor- $\beta 1$ : Tale of a strained relationship. Matrix Biol. 2015, 47, 54-65. [CrossRef] [PubMed]

82. Munger, J.S.; Huang, X.; Kawakatsu, H.; Griffiths, M.J.; Dalton, S.L.; Wu, J.; Pittet, J.F.; Kaminski, N.; Garat, C.; Matthay, M.A.; et al. The integrin $\alpha \mathrm{v} \beta 6$ binds and activates latent TGF $\beta$ 1: A mechanism for regulating pulmonary inflammation and fibrosis. Cell 1999, 96, 319-328. [CrossRef]

83. Khan, Z.; Marshall, J.F. The role of integrins in TGF $\beta$ activation in the tumour stroma. Cell Tissue Res. 2016, 365, 657-673. [CrossRef]

84. Peng, C.; Zou, X.; Xia, W.; Gao, H.; Li, Z.; Liu, N.; Xu, Z.; Gao, C.; He, Z.; Niu, W.; et al. Integrin $\alpha v \beta 6$ plays a bi-directional regulation role between colon cancer cells and cancer-associated fibroblasts. Biosci. Rep. 2018, 38. [CrossRef]

85. Klingberg, F.; Chow, M.L.; Koehler, A.; Boo, S.; Buscemi, L.; Quinn, T.M.; Costell, M.; Alman, B.A.; Genot, E.; Hinz, B. Prestress in the extracellular matrix sensitizes latent TGF- $\beta 1$ for activation. J. Cell Biol. 2014, 207, 283-297. [CrossRef]

86. Klingberg, F.; Chau, G.; Walraven, M.; Boo, S.; Koehler, A.; Chow, M.L.; Olsen, A.L.; Im, M.; Lodyga, M.; Wells, R.G.; et al. The fibronectin ED-A domain enhances recruitment of latent TGF- $\beta$-binding protein- 1 to the fibroblast matrix. J. Cell. Sci. 2018, 131. [CrossRef]

87. Gaggioli, C.; Hooper, S.; Hidalgo-Carcedo, C.; Grosse, R.; Marshall, J.F.; Harrington, K.; Sahai, E. Fibroblast-led collective invasion of carcinoma cells with differing roles for RhoGTPases in leading and following cells. Nat. Cell Biol. 2007, 9, 1392-1400. [CrossRef]

88. Cavaco, A.C.M.; Rezaei, M.; Caliandro, M.F.; Lima, A.M.; Stehling, M.; Dhayat, S.A.; Haier, J.; Brakebusch, C.; Eble, J.A. The Interaction between Laminin-332 and $\alpha 3 \beta 1$ Integrin Determines Differentiation and Maintenance of CAFs, and Supports Invasion of Pancreatic Duct Adenocarcinoma Cells. Cancers 2018, 11, 14. [CrossRef] [PubMed]

89. Iyer, V.; Pumiglia, K.; DiPersio, C.M. $\alpha 3 \beta 1$ integrin regulates MMP-9 mRNA stability in immortalized keratinocytes: A novel mechanism of integrin-mediated MMP gene expression. J. Cell Sci. 2005, 118, 1185-1195. [CrossRef] [PubMed] 
90. Lamar, J.M.; Pumiglia, K.M.; DiPersio, C.M. An immortalization-dependent switch in integrin function up-regulates MMP-9 to enhance tumor cell invasion. Cancer Res. 2008, 68, 7371-7379. [CrossRef]

91. Missan, D.D.; Chittur, S.V.; DiPersio, C.M. Regulation of fibulin-2 gene expression by integrin $\alpha 3 \beta 1$ contributes to the invasive phenotype of transformed keratinocytes. J. Invest. Dermatol. 2014, 134, 2418-2427. [CrossRef]

92. Longmate, W.M.; Lyons, S.P.; DeFreest, L.; Van De Water, L.; DiPersio, C.M. Opposing roles of epidermal integrins $\alpha 3 \beta 1$ and $\alpha 9 \beta 1$ in regulation of mTLD/BMP-1-mediated laminin-gamma2 processing during wound healing. J. Invest. Dermatol. 2017, 138, 444-451. [CrossRef]

93. Zheng, R.; Longmate, W.M.; DeFreest, L.; Varney, S.; Wu, L.; DiPersio, C.M.; Van De Water, L. Keratinocyte integrin $\alpha 3 \beta 1$ promotes secretion of IL-1alpha to effect paracrine regulation of fibroblast gene expression and differentiation. J. Invest. Dermatol. 2019. [CrossRef]

94. He, Y.; Thriene, K.; Boerries, M.; Hausser, I.; Franzke, C.W.; Busch, H.; Dengjel, J.; Has, C. Constitutional absence of epithelial integrin $\alpha 3$ impacts the composition of the cellular microenvironment of ILNEB keratinocytes. Matrix Biol. 2018, 74, 62-76. [CrossRef]

95. Singer, A.J.; Clark, R.A. Cutaneous wound healing. N. Engl. J. Med. 1999, 341, 738-746. [CrossRef]

96. Bridelance, J.; Drebert, Z.; De Wever, O.; Bracke, M.; Beck, I.M. When Neighbors Talk: Colon Cancer Cell Invasion and Tumor Microenvironment Myofibroblasts. Curr. Drug Targets 2017, 18, 964-982. [CrossRef]

97. Bian, X.; Xiao, Y.T.; Wu, T.; Yao, M.; Du, L.; Ren, S.; Wang, J. Microvesicles and chemokines in tumor microenvironment: Mediators of intercellular communications in tumor progression. Mol. Cancer 2019, 18, 50. [CrossRef]

98. Huang, W.; Luo, S.; Burgess, R.; Yi, Y.H.; Huang, G.F.; Huang, R.P. New Insights into the Tumor Microenvironment Utilizing Protein Array Technology. Int. J. Mol. Sci. 2018, 19, 559. [CrossRef]

99. Mitchell, K.; Szekeres, C.; Milano, V.; Svenson, K.B.; Nilsen-Hamilton, M.; Kreidberg, J.A.; DiPersio, C.M.

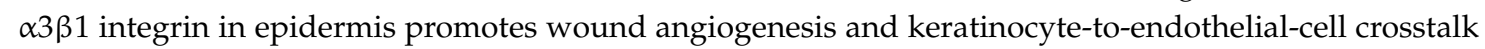
through the induction of MRP3. J. Cell Sci. 2009, 122, 1778-1787. [CrossRef]

100. DiPersio, C.M.; Shao, M.; Di Costanzo, L.; Kreidberg, J.A.; Hynes, R.O. Mouse keratinocytes immortalized with large $\mathrm{T}$ antigen acquire a3b1 integrin-dependent secretion of MMP-9/gelatinase B. J. Cell Sci. 2000, 113, 2909-2921.

101. Toft, D.J.; Rosenberg, S.B.; Bergers, G.; Volpert, O.; Linzer, D.I. Reactivation of proliferin gene expression is associated with increased angiogenesis in a cell culture model of fibrosarcoma tumor progression. Proc. Natl. Acad. Sci. USA 2001, 98, 13055-13059. [CrossRef]

102. Corbacho, A.M.; Martinez De La Escalera, G.; Clapp, C. Roles of prolactin and related members of the prolactin/growth hormone/placental lactogen family in angiogenesis. J. Endocrinol. 2002, 173, $219-238$. [CrossRef]

103. Werner, S.; Krieg, T.; Smola, H. Keratinocyte-fibroblast interactions in wound healing. J. Invest. Dermatol. 2007, 127, 998-1008. [CrossRef]

104. Nowinski, D.; Lysheden, A.S.; Gardner, H.; Rubin, K.; Gerdin, B.; Ivarsson, M. Analysis of gene expression in fibroblasts in response to keratinocyte-derived factors in vitro: Potential implications for the wound healing process. J. Invest. Dermatol. 2004, 122, 216-221.

105. Shephard, P.; Martin, G.; Smola-Hess, S.; Brunner, G.; Krieg, T.; Smola, H. Myofibroblast differentiation is induced in keratinocyte-fibroblast co-cultures and is antagonistically regulated by endogenous transforming growth factor- $\beta$ and interleukin-1. Am. J. Pathol. 2004, 164, 2055-2066. [CrossRef]

106. Tjomsland, V.; Bojmar, L.; Sandstrom, P.; Bratthall, C.; Messmer, D.; Spangeus, A.; Larsson, M. IL-1 $\alpha$ expression in pancreatic ductal adenocarcinoma affects the tumor cell migration and is regulated by the p38MAPK signaling pathway. PLoS ONE 2013, 8, e70874. [CrossRef]

107. Tjomsland, V.; Spangeus, A.; Valila, J.; Sandstrom, P.; Borch, K.; Druid, H.; Falkmer, S.; Falkmer, U.; Messmer, D.; Larsson, M. Interleukin $1 \alpha$ sustains the expression of inflammatory factors in human pancreatic cancer microenvironment by targeting cancer-associated fibroblasts. Neoplasia 2011, 13, 664-675. [CrossRef]

(C) 2019 by the authors. Licensee MDPI, Basel, Switzerland. This article is an open access article distributed under the terms and conditions of the Creative Commons Attribution (CC BY) license (http://creativecommons.org/licenses/by/4.0/). 